\title{
Citizenship Education in Ecuador: Perceptions of Students and Teachers
}

\author{
Andres Alberto Chavez ${ }^{1}$ \\ ${ }^{1}$ School of Management, Universidad Internacional del Ecuador, Guayaquil, Ecuador \\ Correspondence: Andres Alberto Chavez, Guayacanez Mz. 208 V.2 Guayas, Guayaquil, Ecuador. Tel: \\ 593-991-196-070. E-mail: aac2184@tc.columbia.edu
}

Received: February 29, 2016

Accepted: April 15, $2016 \quad$ Online Published: November 27, 2016

doi:10.5539/ies.v9n12p206

URL: http://dx.doi.org/10.5539/ies.v9n12p206

\begin{abstract}
The purpose of this study is to review literature about citizenship education in order to develop a framework for transformative citizenship education and compare that framework to the intended and implemented citizenship education curriculum in Ecuador. This study presents qualitative research carried out in eight schools in four provinces of Ecuador in June 2014. Information was gathered through surveys regarding teacher and student perspectives on the purpose of citizenship education, as well as students' feelings of patriotism, compassion, and appreciation for diversity. Teachers were also interviewed in order to gain understanding about common practices in the classroom and uncover obstacles that teachers face in teaching this course. Based on the surveys and teacher interviews, it is evident that there are some obstacles to the successful implementation of citizenship education in Ecuador. Two main obstacles are a lack of resources, including textbooks, as well as a shortage of participatory class activities and projects.
\end{abstract}

Keywords: citizenship education, educational policy, development, curriculum, Ecuador

\section{Introduction}

Between the years of 1997 and 2007, there were eight different presidents in power in Ecuador. Leaders were removed from office in various ways, from being unseated by Congress to being overthrown by a coup d'état. This was a time of great economic instability in the country, and people hoped that changing the president would improve their financial prospects. The people of Ecuador during this time participated in the political process primarily through the format of protesting. By loudly voicing their discontent, holding demonstrations, and using violence, the general population found ways to instigate and hasten the removal of the leaders that they did not feel were representing them as they wished. However, these actions did little to improve the situation of Ecuador's citizens. The problem was that the people of Ecuador had not been properly educated about the power that they held as citizens. Based on their actions, it appears that they believed that they needed the perfect president to make things better for them, and consequently they focused on finding a better leader rather than striving to enact positive change themselves.

Education is the most effective tool that can be used to empower citizens to become agents of change. The government of Ecuador has increased its investment in education in recent years as the economy has improved. Public expenditure on education as a percentage of national GDP averaged 1.5\% between the years of 1998 to 2001; the average rose to $4.4 \%$ between the years of 2010 to 2012 (World Bank, 2014). Citizenship education is one component of education that is particularly geared towards teaching students the rights and responsibilities they have as members of their nation and communities. In Ecuador, separate citizenship education courses have only been taught in public schools since 2012. Prior to this, concepts related to citizenship education were taught only in other social science classes. Components of citizenship education continue to be taught in social science classes for younger students, as separate citizenship education courses are given only to students in their last two years of high school.

According to the Ministry of Education in Ecuador, the primary objective of citizenship education is for students to 'understand and value the basic principles of Ecuadorian democracy in order to exercise independent, participatory, and responsible citizenship, and assume a personal, defined and independent position regarding dilemmas or controversies in social life' (MOE, 2012a). Additionally, the Ministry has stated that rather than transmit facts and rules to students, the result of citizenship education classes should be 'to diminish the passive 
participation of individuals in the political sphere and generate efficient citizenship training' (MOE, 2012a, p. 3). Therefore, the intent of citizenship education is that students learn to actively participate in their communities and fully exercise the potential of their citizenship. The purpose of this paper is to thoroughly define citizenship education and its objectives, and explore perspectives of teachers and students regarding how citizenship education is being implemented in Ecuador. Additionally, current education practices will be analyzed in light of the literature in order to uncover some of the challenges that prevent citizenship education in Ecuador from reaching its potential in preparing students to be active citizens.

\section{Citizenship Education Theoretical Framework}

Just as an atom is the basic unit of a cell, a citizen is the basic unit of a community. A single atom cannot accomplish much on its own, but it joins with other atoms to form meaningful matter. Likewise, one individual citizen is limited in his ability to impact society, but by joining with others, he can create meaningful changes. The word 'citizen' itself implies the necessity of collaborating with others, as it is derived from the Latin word 'civitas' meaning "people united in a city or community" (UNESCO, 2010a, p. 1). It is logical, therefore, that the purpose of citizenship education would be to teach citizens how to live and work together. A common definition of the word 'citizen' lends additional insight into how citizens should be instructed. According to Heater (1990), "a citizen is a person with knowledge of public affairs, instilled with attitudes of civic virtue and equipped with skills to participate in the public arena" (p. 336). Thus, citizenship education should be concerned with helping students learn about their nation and community and the issues therein, expanding their mindsets so that they have a desire to improve on the issues, and providing them with opportunities to develop the abilities they need to successfully address these issues. It is vital that citizenship education contribute to these areas of student development because sustainable societies are necessarily comprised of active citizens working together democratically (UNESCO, 2010a, p. Introduction).

According to Banks (2008), there are two types of citizenship education, which are mainstream and transformative; the former is 'grounded in mainstream knowledge and assumptions and reinforces the status quo and the dominant power relationships in society...It does not challenge or disrupt the class, racial, or gender discrimination in the schools and society' (p. 135). In other words, mainstream citizenship education teaches students how society and the government function, and reinforces their current role in that process. Its main objective is to transmit information to students regarding how programs and processes are carried out in the public sector. The material covered in such classes is mainly descriptive; students are taught how things are done, and the end objective of the course is that they understand how the government functions. Students in mainstream citizenship education classes will typically be evaluated based on their ability to memorize facts and repeat information that has previously been taught to them.

Transformative education, on the other hand, 'helps students to develop the decision-making and social action skills that are needed to identify problems in society and acquire knowledge related to their homes and community' (Banks, 2008, p. 135). This type of citizenship education encourages students to critically look at the condition of their society and equips them to find solutions to the challenges that they see. Students in such a course learn not only how the government works, but are also able to examine how it doesn't work. They prepare to become active contributors in their communities by finding issues and inequalities in their societies, and learning how to address these problems. Parker (1996) agrees that citizenship education's focus must go beyond voting and campaigning; it must involve the development of people's capacities to think creatively and act accordingly.

The focus of this research is transformative citizenship education, which aims to help students not only understand their rights and responsibilities as citizens, but to prepare them to exercise those rights and responsibilities in order to successfully participate in their country and communities. The purpose of transformative citizenship education is to open students' minds to their potential for transformative citizenship in their country. This type of citizenship extends to activities beyond the existing social structure in order to promote values like social justice and equality. People who exercise transformative citizenship are ready to act in order to increase equality, even if that means acting against established laws (Banks, 2008).

In order for citizenship education to prepare students to participate in this way, the classes themselves should be highly participatory. Rather than focusing on memorizing correct answers, the activities done in class should be geared towards helping students to become politically aware; one way that this can be achieved is by holding honest and direct conversations, based on both facts and opinions, in which students are free to decide for themselves how they feel about the issue at hand (Harber \& Mncube, 2012). A more participatory education will help students to develop the ability to think critically as they attempt to find their own solutions to problems 
(Torney-Purta \& Amadeo, 2004). If the goal of citizenship education is to transform students into active citizens, then employing participatory teaching tactics is essential because they are "motivating, humanizing and ultimately practical, since this form of learning is linked more strongly with attitudinal or behavior change than with a pure lecturing approach" (Tibbitts, 2002, p. 162). Pure lecturing is an ineffective and limited teaching method, as it attempts to direct and control what students think. This limits their ability to think critically and also takes away from their freedom, which is counterproductive to the development of a nation. As Amartya Sen (1999) explained, development is aimed towards broadening the range of freedoms that people experience. Citizenship education should enlarge people's access to their rights, rather than diminish them, and should provide them with the space and flexibility necessary to develop their unique perspective on the current reality and future potential of their society.

One of the skills that students should learn through participatory citizenship education courses is dialogue. Dialogue is essential to democracy, and one of the main problems that democracies face is that the dialogue focuses too much on talking and not enough on listening. Some of the key qualities that citizens in democracy need to develop are "the ability to listen to others, to concur with others, to negotiate differences, to recognize one's own rights and the rights of others...to tolerate differences and to accept cultural diversity and diversity in the choices others make" (Cox, Jaramillo, \& Reimers, 2005, p. 8). Students cannot learn these skills by listening to a teacher talk about them. Rather, they are learned through practice and experience. Students must practice speaking and listening, and they also need to have the empowering experience of being heard. If a student can engage in honest, open, and courteous dialogue with his peers and teachers, he will learn to truly listen and cooperate. This will allow him to be successful in collaborating with others to find answers that are better than those that he could have come up with on his own, as he learns to listen to others as equals and be flexible in his thinking in order to forge a cooperative solution (Cox, Jaramillo, \& Reimers, 2005). Engaging in this type of dialogue in the classroom will prepare him to be a citizen capable of uniting with others to improve his community.

Additionally, it is important that students have the opportunity to make decisions in a democratic setting in the classroom so that they will understand what it means and how it feels to be an active participant. Democratic classrooms necessarily involve a decrease in the teacher's power as an authority figure and an increase in the students' power as freethinking autonomists. This power shift can be accomplished in various ways, such as involving students in making decisions regarding the class rules, curriculum, teaching methods, and assessment measures (Harber \& Mncube, 2012, p. 55). Direct involvement in the learning process is crucial to students' success. When students are not able to actively learn by using their own bodies and senses, "the subject matter of instruction is isolated from the needs and purposes of the learner, and so becomes just a something to be memorized and reproduced upon demand" (Dewey, 1916, p. 192). However, if participating in a process becomes personally meaningful to them, they will seek to be active citizens in the forums that they can, and find ways to change the flawed structures where they currently cannot. They will feel the power and excitement of contributing their voice for the greater good, and once they have that experience, they will not want to exercise their citizenship in any lesser way. Students will desire to act both individually and in organized groups on a daily basis in an effort to enhance social progress and quality of life (Arana, 2007). The amount of time that a citizen spends in democratic actions should far exceed the few minutes that it takes to cast a vote during an election. For citizens to participate more fully, they must come to see "democracy as a practice, and not solely a system" (IIDH, 2007, p. 41). This requires that students learn more than the facts about how democracy is supposed to function by actually practicing democracy and coming to understand their role in it within their sphere of influence.

Through direct participation in the political process, children are able to gain "a genuine appreciation of democracy and a sense of their own competence and responsibility to participate" (Hart, 1997, p. 3). It is essential that students gain this competence to participate because that will enhance their confidence to participate. It is human nature for a person to shy away from things that he does not understand or that he does not feel capable of performing. Someone who never learned to swim as a child will be reluctant to come near a body of water for fear of drowning. Likewise, someone who has never participated in the political process will hesitate to voice an opinion or start a campaign for fear of saying the wrong thing or not getting enough support. Children need to begin participating in political processes while they are still young so that they will have the competence and confidence to take a stand and make a difference.

In order to crystallize the knowledge and skills that students acquire through citizenship education and lay a foundation for the remainder of their lives as citizens, students should participate in projects that allow them the opportunity to get involved in their community. UNESCO states that citizenship education should always be 
accompanied by action, through which students are encouraged to address issues and enact change at local, national, and international levels (as cited in UNESCO, 2010a). For example, through citizenship education courses, students in Lyneham Primary School in Australia have the opportunity to exercise local and international citizenship. At the local level, students participate in a program where they lead groups of younger students in learning social skills such as befriending others, being helpful, and dealing with peer pressure. This program has been found to increase students' responsibility, empathy, and self-esteem. Additionally, students in the citizenship education courses at this school correspond with a foster child from a different country. They learn about the child's life and also raise funds to sponsor the child's education and living expenses. This program helps students to become "global citizens, caring for and participating in global action to help someone else" (UNESCO, 2010a, p. 3). Projects such as these that provide opportunities for students to develop positive and collaborative attitudes and skills are essential to students' development as active citizens.

Effective citizenship education courses focus on helping students to become agents of change, provides a space for them to have a voice and be heard, empowers active students through critical thinking, and encourages them to apply the knowledge that they acquire by participating in their communities. This is best accomplished by making classroom learning participatory and democratic, giving students opportunities to speak and listen in open and constructive dialogue, and linking education to action through community and global projects. These are the key features that orient pedagogies towards transformative citizenship in the sense that students are able to apply the principles of democracy and human rights, and this is the basic framework that the author will apply to the intended and implemented curriculum in Ecuador.

\section{Methodology}

There were four key questions that guided this study, which were:

1) What should citizenship education courses teach and how should they be taught?

2) What goals does the Ministry of Education in Ecuador have for citizenship education?

3) How is citizenship education being implemented in Ecuador and how applicable is it to students' lives?

4) What limitations exist that impede the effective implementation of citizenship education?

In order to address these questions, a literature review was first compiled in order to identify the essential components of citizenship education and develop a framework for how these courses can best help students to become transformative citizens, who are citizens that 'take action to actualize values and moral principles beyond those of conventional authority' (Banks, 2008, p. 137). Then, the intended curriculum for citizenship education in Ecuador was analyzed against the framework developed from the literature review. Lastly, information about the implemented curriculum in four schools in Ecuador was gathered in order to gain an understanding of how citizenship education is currently being administered in the country.

The author visited the four provinces of Guayas, Pichincha, Esmeraldas, and Imbabura. Guayas and Pichincha are the largest provinces in Ecuador, and mestizos form the majority of the population. Esmeraldas is mostly populated by Afro-Ecuadorians, and Imbabura is mostly populated by indigenous people. These provinces were chosen because the author wanted to see if there were noticeable differences in the way citizenship education was implemented among different ethnic groups.

In each province, the author visited one rural and one urban school, using a computer-generated stratified randomizer to determine which eight schools to include in the sample. Information was gathered from students and teachers through written surveys. Surveys were distributed to every citizenship education classroom for Juniors and Seniors in each school visited. The teachers and students filled them out, and the author collected them at the end of class. Eight teachers and 410 students filled out surveys for this study.

The student survey consisted of seventeen questions; three of these questions were taken directly from a survey designed by the International Civic and Citizenship Education Study (ICCS) research team, and the rest were formulated by the author and his academic advisor. The teacher surveys also consisted of seventeen questions formulated by the author and his academic advisor. In addition to the surveys, the author held 30-minute interviews with one teacher from each school visited, which were recorded and later transcribed and translated. Most of the schools that were visited had only one teacher who gave the citizenship education course; in the schools with two teachers for the course, the principal decided which one would be interviewed.

\section{Findings}

\subsection{Intended Curriculum for Citizenship Education}

Before explaining the findings of this research regarding the way citizenship education is implemented in 
Ecuador, it is important to explore the intended outcomes of the course. In 2008, President Rafael Correa and his assembly wrote a new constitution for Ecuador. Major changes were made to the way education was to be administered throughout the country. Article 27 of the 2008 Constitution of Ecuador reads,

Education will focus on the human being and shall guarantee holistic human development, in the framework of respect for human rights, a sustainable environment, and democracy; education shall be participatory, compulsory, intercultural, democratic, inclusive and diverse, of high quality and humane; it shall promote gender equity, justice, solidarity and peace; it shall encourage critical faculties, art and sports, individual and community initiatives, and the development of competencies and capabilities to create and work. Education is indispensable for knowledge, exercise of rights and building a sovereign country and it is a key strategy for national development (MOE, 2012b).

In an effort to fulfill this goal, a new curriculum was developed for citizenship education courses in 2012. Prior to this, the concepts of citizenship education were briefly taught in other social studies courses.

The Ministry of Education in Ecuador has published guidelines regarding the objectives of citizenship education in the country and how the classes should be orchestrated. The first objective that they list is for students to 'understand and value the basic principles of Ecuadorian democracy in order to exercise independent, participatory, and responsible citizenship, and assume a personal, defined and independent position regarding dilemmas or controversies in social life' (MOE, 2012a). This objective highlights the participatory aspect of transformative citizenship education and shows that, as a result of their education, students should be able to think critically to form their own opinions and then be proactive in acting on those opinions. The second objective set forth by the Ministry of Education is that students 'understand the two dimensions of democracy; as a form of government and as a way of life, through reflective analysis of citizens' power and the defense of rights to engage in the mechanisms of democratic participation' (MOE, 2012a). This statement supports the idea of transformative citizenship by explaining that citizenship should be exercised daily and used to secure rights for everyone to participate.

Another listed objective of citizenship education is to 'analyze social conflicts and the democratic means for resolving them, recognizing the functions and relationships of the groups involved, as well as the different perspectives and interests that are involved' (MOE, 2012a). Pursuit of this objective in the classroom would help students learn about dialogue, specifically about listening and attempting to understand other people's perspectives and viewpoints, and it would also teach them about conflict resolution and various techniques for collaborating with others. One other objective states that students should 'recognize the Constitution of Ecuador as the instrument that allows the institutional organization of the state for the efficient use of the rights of citizenship' (MOE, 2012a). This objective clearly states that it is important for students to be familiar with the Constitution because it is through its principles that citizens can fully exercise their rights. Teaching students about the organization of their country's governing principles and the rights that they have through the Constitution should make them more competent and capable as active citizens. Knowing their rights will make them more likely to claim them, and they will also strive to stamp out social injustices when they see that certain rights are not being extended either to themselves or someone else.

As for how the classes should be taught, the Ministry of Education has said explicitly that these courses are 'not a simple transmission of facts, concepts, and rules that teach people to vote or choose authorities' (MOE, 2012a, p. 3). They emphasize that the result of these classes should be 'to diminish the passive participation of individuals in the political sphere and generate efficient citizenship training' (MOE, 2012a, p. 3). This is consistent with the aforementioned objectives; the Ministry of Education wants students to actively participate in these classes so that they can learn to actively participate in their communities. They further state that these classes should help students develop the tools that they need so that can think critically, reflect on the meaning and purpose of laws, argue for and against various platforms, debate constructively with others in order to see different perspectives and find possible solutions, and develop collective action and social compromise in the pursuit of a meaningful life for all citizens (MOE, 2012a, p. 4). All of these tools are critical in shaping students to be future leaders and agents of change. Above all, the Ministry of Education states, it is necessary that adolescents feel recognized as part of the school project, class group, and educating community in general. At the same time, it is necessary that they feel heard and positively valued in some aspect of their daily work in school' (MOE, 2012a, p. 10).

Therefore, the intended curriculum for citizenship education in Ecuador is participatory, teaches students to engage in open and constructive dialogue, and emphasizes the importance of action, particularly in a 
collaborative sense. This aligns with the framework for transformative citizenship education as presented in the literature review. Whether the curriculum and the transformative framework have been implemented as intended in the classes that were visited across Ecuador will be analyzed in the subsequent sections.

\subsection{Surveys}

\subsubsection{Purpose of Citizenship Education}

As stated in the literature review, the goal of citizenship education is to transform students into active citizens capable of enacting change. The results obtained from the surveys show student and teacher perspectives about citizenship education courses, as well as the attitudes and morals that are thought to be fostered by citizenship education. The first item on the survey for both students and teachers was an open-ended question that asked them to supply the primary purpose of citizenship education. Teachers' answers mainly portrayed the general idea of teaching students to be good citizens and to coexist well with others. Only one teacher elaborated on what it means to be a good citizen; he said that the purpose of the course was 'to form and train good citizens, who know their responsibilities and rights, live their values, and are sympathetic, participative, proactive, and critical'(Teacher Survey, 2014). Another teacher simply stated that the purpose was 'to have a good life' (Teacher Survey, 2014).

Students' answers, on the other hand, demonstrated a larger variety of opinions. Several students left the answer blank, and others commented that they did not know. A common answer was that the purpose of the class was to learn about the government, and many students mentioned that the purpose was to learn the rules and regulations of their country. Numerous students provided vague responses about how the purpose of the class was to help them learn material that they would be able to use in the future. Only a few students wrote answers that aligned with the purposes of transformative citizenship education. One student explained that the purpose was 'for all students to understand our responsibilities, rights, and values, and that every day we put them in practice in our personal lives and neighborhoods' (Student Survey, 2014). Another student added that the purpose was to 'learn about the necessities or problems that can arise in a city or community, and how to solve those problems of the inhabitants or citizens in order to encourage the rights and obligations that each of us have' (Student Survey, 2014).

This wide range of answers demonstrates that most students are not aware of the true purpose of citizenship education, which the Ministry of Education (2012a) explained was to 'understand and value the basic principles of Ecuadorian democracy in order to exercise independent, participatory, and responsible citizenship, and assume a personal, defined and independent position regarding dilemmas or controversies in social life' (p. 1). The fact that none of the teachers' answers fully conveyed that purpose may indicate that they do not have a full understanding of the purpose of the citizenship education courses that they teach. This is an issue that needs to be addressed in order for citizenship education to fulfill its purpose.

In addition to the open-ended question, teachers and students were provided with a list of objectives and asked to indicate which ones represented main goals of the course.

Table 1. Learning objectives in citizenship education courses

\begin{tabular}{lcc}
\hline & Students agree (\%) N=410 & Teachers agree (\%) N=8 \\
\hline Learn how the government functions & 42.7 & 87.5 \\
Learn about human rights & 69.8 & 100 \\
Learn about the rights and obligations of citizens & 54.9 & 75 \\
Learn about the national emblems & 13.2 & 87.5 \\
Learn about national history & 23.7 & 87.5 \\
Learn values and moral principles & 75.6 & 100 \\
\hline
\end{tabular}

Table 1 shows various learning objectives for citizenship education and the percentage of students and teachers in the study who agreed that each objective is one of the goals of the course. The percentage of teachers who agreed on an objective was significantly higher than the percentage of students who agreed in every case. One possible interpretation of these results is that teachers marked the objectives that they knew should be taught and students marked the objectives that were actually taught. This would indicate a disparity between the intended 
and implemented curriculum in citizenship education courses. The discrepancies between teacher and student answers offer further evidence that teachers and students are not communicating openly regarding the purposes of citizenship education. Otherwise, their answers would align more closely.

\subsubsection{Student Sense of Patriotism}

The first set of ICCS questions that were used in the survey were intended to measure students' sense of patriotism. Figure 2 shows the survey questions and the students' responses.

Table 2. Student sense of patriotism: Ecuador Item Frequencies (row percentages) $\mathrm{N}=376$

\begin{tabular}{|c|c|c|c|c|}
\hline The flag of Ecuador is important to me. & 1.6 & 4.3 & 50.4 & 43.7 \\
\hline The political system in Ecuador works well. & 4.5 & 40.6 & 47.3 & 7.6 \\
\hline I have great respect for Ecuador. & 2.7 & 2.4 & 43.2 & 51.7 \\
\hline $\begin{array}{l}\text { In Ecuador we should be proud of what we } \\
\text { have achieved. }\end{array}$ & 2.7 & 6.1 & 44.3 & 46.9 \\
\hline I am proud to live in Ecuador & 1.6 & 2.4 & 37.2 & 58.8 \\
\hline $\begin{array}{l}\text { Ecuador shows a lot of respect for the } \\
\text { environment. }\end{array}$ & 2.8 & 18.6 & 50.1 & 28.5 \\
\hline $\begin{array}{l}\text { Generally speaking, Ecuador is a better country } \\
\text { to live in than most other countries. }\end{array}$ & 2.4 & 11.9 & 50.4 & 35.3 \\
\hline
\end{tabular}

$\square$ Strongly disagree $\quad$ Disagree $\backsim$ Agree $\quad$-Strongly agree

Question 2 was by far the most divisive for Ecuadorian students. The combination of students who strongly disagreed and disagreed indicates that $45.1 \%$ of students were not in agreement with the statement that the political system in Ecuador works well. The next largest split was whether Ecuador shows a lot of respect for the environment, to which $21.4 \%$ of students indicated disagreement. In question 7, 14.3\% of students indicated that Ecuador is not a better place to live than most other countries. This is a noteworthy percentage of students who feel they would be better off living somewhere else. Fewer than $10 \%$ of students disagreed with the remaining items.

\subsubsection{Student Sense of Compassion}

Table 3 shows student responses for the second set of questions from the ICCS research, which were intended to measure students' sense of compassion. Compassion is an essential aspect of citizenship education because oftentimes the most marginalized people in society do not have access to quality education. It is therefore unlikely that a marginalized person will have the opportunity to learn the skills necessary to increase equality for his people. However, a student who is fortunate enough to receive a good education and learn the skills of an active citizen will have the desire to improve the situation of marginalized people in his country and community if he has compassion for others. The prompt for the question was, 'How do you feel when you witness the following situations at school?'

Table 3. Student sense of compassion: Ecuador Item Frequencies (row percentages) $\mathrm{N}=381$

How do you feel when you witness the following situations at your school

\begin{tabular}{lcc|c}
\hline A classmate falls and gets hurt. & 15.8 & 37.7 & 46.5 \\
A classmate gets beaten up. & 2.4 & 12.6 & 85.0 \\
A classmate gets unfairly reprimanded. & 2.7 & 14.9 & 82.5 \\
A classmate gets unfairly punished. & 2.9 & 7.9 & 89.2 \\
A classmate gets something stolen from him/her. & 2.6 & 12.3 & 85.0 \\
A classmate gets ridiculed. & 6.4 & 19.8 & 73.7 \\
A classmate gets insulted. & 2.7 & 19.6 & 77.7 \\
\hline
\end{tabular}




\begin{tabular}{lll|l|}
\hline A classmate looks very sad. & 3.9 & 32.8 & 63.4 \\
A classmate gets bad grades. & 4.3 & 58.4 & 37.3 \\
A classmate has nobody to play with. & 3.3 & 32.2 & 64.5 \\
\hline
\end{tabular}

I think it is fun $\mathbf{I}$ don't care $\mathbf{a}$ It bothers me

The majority of Ecuadorian students in the study responded that they were bothered by the various situations of a classmate suffering in some way, with the exceptions of a classmate falling and getting hurt and a classmate getting bad grades. The majority of students indicated that they did not care about either of these situations. $15.8 \%$ of students indicated that they thought it was fun to see a classmate fall and get hurt, and $6.4 \%$ thought it was fun to see a classmate get ridiculed. Fewer than 5\% of students indicated that any of the other scenarios were fun. The situation that bothered the most students, at $89.2 \%$ of the sample population, was a classmate getting unfairly punished.

\subsubsection{Student Appreciation for Diversity}

Table 4 shows student responses regarding how they would feel interacting with people from various backgrounds and groups in order to gauge their appreciation for diversity. Appreciation for and openness to diversity are crucial concepts in citizenship education, as they are critical to people uniting together for the greater good. The ICCS research showed that students whose scores reflected more positive attitudes toward diversity tended to score higher in tests of civic knowledge (Schulz, Freidman \& Leitz, 2009). This suggests that there is a correlation between learning concepts in citizenship education and appreciating diversity. The prompt for this question was, 'How do you feel when you associate with the following types of people in your school?'

Table 4. Student appreciation for diversity: Ecuador Item Frequencies (row percentages) N=387

\begin{tabular}{lll|l|}
\hline People with different skin color than yours. & 2.1 & 28.2 & 69.8 \\
People of a different social class than yours. & 1.6 & 35.4 & 63 \\
People of a different religion than yours. & 3.8 & 42.0 & 54.2 \\
Homosexuals or lesbians. & 29.7 & 43.2 & 27.0 \\
People who come from another region of the country. & 2.6 & 25.7 & 71.7 \\
People with physical disabilities. & 3.8 & 33.1 & 63.1 \\
People with mental disorders. & 20.1 & 42.9 & 37.1 \\
People of a different nationality than yours. & 2.7 & 35.1 & 62.2 \\
People with AIDS. & 23.9 & 44.6 & 31.5 \\
People of indigenous origin. & 2.4 & 39.7 & 57.8 \\
\hline
\end{tabular}

$\square$ I would dislike it $\square$ I wouldn't care $\mathbf{\square}$ I would like it

According to their responses, Ecuadorian students reacted most negatively to homosexuals and lesbians, people with mental disorders, and people with AIDS. It is interesting to note that there were more students that reported that they would dislike interacting with a homosexual or lesbian than students who reported that they would like it, especially since $62 \%$ of teachers indicated in their surveys that appreciation for people with different sexual orientations is promoted by citizenship education courses (Teacher Surveys, 2014). Additionally, there were significantly fewer students who indicated that they would like interacting with people of different religions and people of indigenous origin than there were who indicated that they would like interacting with people of the remaining groups. Teachers unanimously indicated in their surveys that appreciation for other cultures and ethnicities, which should include indigenous people, is promoted by citizenship education. However, only $57.8 \%$ of students indicated that they would like to interact with indigenous people. This suggests the need for a greater emphasis on the value of indigenous people in citizenship education.

\subsection{Teacher Interviews}

Each of the eight teachers that were interviewed was asked how long they had been teaching and what degree of education they had obtained. All but one of the teachers had the required credentials to teach, and all but two 
teachers had at least thirty years of teaching experience. One teacher had completed a master's degree in education. Thus, the majority of teachers included in the sample were highly experienced. However, due to the newness of the course in Ecuador, these teachers only have two years of experience teaching citizenship education.

In discussing teachers' pedagogical strategies with them in the interviews, it was evident that teachers most commonly used lectures, class discussions, and group activities. Most teachers did not seem to have an understanding of how they could facilitate open dialogue among students and encourage greater participation. Only one teacher had students carry out a project that is described in the textbook in which students identify a problem in their communities, research the problem, interview community members about the problem, and provide possible recommendations to address the problem. Their goal in preparing the project is to present it in the mayor's office. This teacher observed, 'Students learned to carry out a citizen's project because the Constitution of Ecuador manifests that all citizens have the right to carry out such projects' (Personal Interview, 2014). This is consistent with the framework of citizenship education, which emphasizes the importance of students participating in projects that help them get involved with the community. The effort that students put into carrying out their project formed a major part of their grade for the class, whereas in other classes, grades were mostly based off of students' ability to memorize facts and definitions for tests. The inclusion of such a project that encourages students to work with other members of the community towards a greater cause is consistent with the framework of transformative citizenship education.

Several teachers thought that the curriculum should include teaching about practical values such as sex education. According to the framework, part of transformative citizenship education is helping students learn about issues in the community, and teachers feel that the lack of proper sex education is an issue in Ecuador. One teacher explained, 'We see a lot of pregnant students in fifth, sixth, and seventh grade because the students do not have a life plan or understanding of ideals and values' (Personal Interview, 2014). In the sixteen classrooms that the author visited, he saw three teenage girls that were noticeably pregnant. Another girl brought her three-month-old baby to class with her. Teen pregnancy is an issue that could be improved by effective sex education, and since the students are not receiving this type of education in any other class, it may be beneficial to add it to the curriculum of citizenship education. This is practical information that will help them lead higher quality lives and act responsibly in their personal relationships. It will also help them see firsthand how education can be used to address relevant issues in the community.

The most common complaint from teachers was that they lacked the resources that they felt were necessary to make the course relevant and salient. Three teachers specifically mentioned that it would be of great help to them to have televisions and videos or DVDs in the school so that they could clarify and expand on the concepts that they were teaching. As one teacher commented, 'Explaining what is taught in the textbook is not the same as watching a video about someone who has had a problem and seeing how they overcame it so that students can see it and live it as well' (Personal Interview, 2014). A teacher who did have access to a television and videos that accompanied the textbook expressed how helpful those resources were in his teaching. He explained that he liked to show videos as often as he could to complement class discussions, and he reported, 'Students also find videos and bring them to share with the class' (Personal Interview, 2014). Utilizing technology in this way presents an effective forum for students to actively participate in their learning, as the framework indicates that they should. They have the opportunity to engage with the material by finding relevant videos to share with each other, and by so doing take some ownership in the class. Teachers who do not have access to this technology are not able to present the entire curriculum as intended by the Ministry of Education.

Another point of concern was that two of the teachers had not received a copy of the textbook for the course. One of these teachers did not know that the Ministry of Education had published a textbook for the course. She said, 'I download content from the internet to give to the students since they do not have textbooks for the class. They have textbooks for physics, chemistry, mathematics, biology, and natural sciences, but there is no textbook for social studies courses' (Personal Interview, 2014). The other teacher knew that there was a textbook, but said that she had not yet received it. She explained, 'I have friends that have lent me books; I take care of them and don't mark in them, and I follow the guidelines that I have found online. The students don't have books to work in but I have a borrowed copy' (Personal Interview, 2014). Other teachers mentioned that they had copies of the textbook, but that their students did not because they could not afford to purchase them. The textbook contains several homework assignments and in-class activities to enrich the course, but many teachers choose not to use these materials since they have students who do not have their own copy of the book. As a result, oftentimes teachers resort to doing more lectures than interactive activities because they feel the need to disseminate the knowledge from the textbook. 


\section{Discussion}

One issue that was apparent from the surveys was that teachers and students in Ecuador lack a full understanding of the purpose of citizenship education courses. This is problematic because the class cannot reach its potential for cultivating active citizens if teachers and students do not have a vision and comprehension of that potential. Making this purpose clearly known to teachers and students would help them direct their activities towards it and thereby work more effectively to fulfill it. A simple introductory unit at the beginning of the course in which teachers help students discover the purpose of citizenship education would help teachers and students alike to focus their efforts for the duration of the course on understanding democracy, exercising citizenship, and forming positions on social issues. This introductory unit should be carried out almost exclusively through interactive dialogue between the teacher and students, as discussed in the theoretical framework (Cox, Jaramillo, \& Reimers, 2005) so as to set the standard for full engagement and participation in the course for each student. Additionally, all material presented in the course should be linked back to the discovered purpose so that students can understand more clearly how to apply the concepts that they are learning.

Survey results also indicated that there is a discrepancy between what teachers think they are teaching and what students think they are learning. For example, although $100 \%$ of the teachers included in the study reported that one of the main objectives of the course was to learn about human rights, only $69.8 \%$ of students included in the study reported that learning about human rights was a main objective of the course. This indicates a need for more open communication between teachers and students, as well as a more democratic classroom setup where students can contribute to the formation of class objectives and actively participate in their learning of the objectives. It was mentioned in the framework that students must come to see "democracy as a practice, and not solely a system" (IIDH, 2007, p. 41). In order for this to happen, they should see their citizenship education course in the same way; not merely as a system, that transmits information to them which they later report back in an exam and then promptly forget, but as a practice that changes the way they see and experience the various course objectives, such as human rights. Merely hearing information about human rights would reasonably lead some students to question whether they had learned about it in the course, and if it had been one of the main objectives. Having an open dialogue about ways that students have seen or experienced violations of human rights, or participating in a project where they were able to help others more richly take advantage of their human rights, would help more students to internalize human rights as a main objective of their lives, as well as a main objective of the course. By encouraging students to live the objectives, teachers could help to ensure that students are learning the intended objectives of the course in such a way that they will not easily forget them.

Almost half of the students included in the sample (45.1\%) indicated that they disagreed with the statement that the political system in Ecuador works well. This statistic is important because it shows that changes need to be made in the political system in order for students to feel a greater sense of patriotism. Those who plan the curriculum for citizenship education courses and those who teach it need to be aware of this issue so that they can prepare students to be the citizens who make these changes. Students need to be taught how they can participate in the political system in a meaningful way that will improve the way that it functions. If students can feel some ownership in the political system through their participation in it, and their potential for future participation in it, they will come to see it in a more positive light. Students who have the opportunity to directly participate in politics come to obtain a profound gratitude for the democratic process (Hart, 1997). Helping students learn how to actively participate in democracy will likely improve the sustainability of the democracy in Ecuador, and will lead to increased satisfaction among citizens with the nation's political system.

Despite teacher reports that citizenship education courses promote appreciation for other cultures and ethnicities, only $57.8 \%$ of the students included in the study indicated that they would like to interact with indigenous people at their school. This suggests the need for a greater emphasis on the value of indigenous people in citizenship education. One simple method for addressing this issue would be to use indigenous stories to illustrate various concepts throughout the course. UNESCO (2010b, p. 4) states, 'Indigenous stories are extremely valuable in Education for Sustainable Development because they have a different message to the stories commonly told on television and in movies and advertising'. It would be particularly poignant if non-indigenous students were given the opportunity to interact with indigenous students in some way, either in person or through writing. These positive interactions would contribute substantially to the unity of Ecuador's people.

The weak positive correlation $(\mathrm{r}=2.68)$ between students who reported the class was applicable to their lives and students who reported feelings of empathy for others indicates that many students are not actively applying the concepts they are learning to their lives. One classroom activity that could help strengthen this correlation is open and constructive dialogue, as discussed in the framework. As students learn to listen to one another and allow themselves to be affected by hearing another's point of view, they will develop more understanding and 
ultimately more compassion. Engaging in dialogue with others allows a person to step outside of himself and see the world from other perspectives, which changes the way that he views those around him, as well as those he has not yet met. A student who develops such empathetic characteristics is well on his way to become a transformative citizen capable of uniting with others in order to enact positive change (UNESCO, 2010a).

Several teachers indicated that they did not have adequate resources to follow the curriculum for citizenship education. The most common complaint was the lack of televisions and DVD players in the classrooms. There are two main ways that this issue can be addressed. The first is the obvious solution of providing funding so that each classroom has adequate technology. This will require an increase in funding to schools, as well as changes in the way that the government administers the budget. The second solution is to use other mediums of storytelling, such as novels and songs that introduce students to other cultures and ways of life, as well as characters who have overcome difficulties. Stories, no matter the form they take, are poignant teaching tools because they 'have the power to reach within us, to command emotion, to compel involvement, and to transport us into timelessness... stories are a way in which we can know, remember and understand' (Livo \& Rietz, 1986, p. 2). Whether stories are communicated through DVDs, written words, or a teacher's voice, they should not be overlooked in the dissemination of the curriculum in citizenship education courses.

Two of the eight teachers that were interviewed did not have a copy of the textbook for the course, and several mentioned that they did not have enough copies for their students. It is the responsibility of the government to provide textbooks to teachers and students in public schools in Ecuador. This is simply an issue that the government needs to rectify as soon as possible. In the meantime, there are some high quality online resources that teachers can use to prepare their lessons, which include activities for students to do in order to get involved. However, if the Ministry of Education wants citizenship education courses to be delivered in line with the curriculum and objectives that they have formulated, they need to ensure that all teachers and students are equipped with the proper materials, beginning with the textbook.

Only one teacher included in the study gave students the opportunity to carry out a project described in the curriculum that allows them to interact with the community as they investigate an issue within their neighborhood. Projects such as this one give students the crucial opportunity to develop their skills for participating more fully in society' (UNESCO, 2010a, p. 3). Students learn how to be active citizens by actually being active citizens. Greater emphasis needs to be placed on exercising active citizenship inside and outside of the classroom. There are several ways that these projects can take shape. UNESCO (2010a) has provided several examples of activities that students can engage in, which fall into the categories of negotiating school rules and policies, participating in school and community organizations, developing skills and knowledge in school subjects, and decision-making in different settings within the school. Teachers should choose projects that are appropriate for their students and tailored to the unique needs and opportunities in their communities. In this way, both students and communities can benefit from the experience.

\subsection{Limitations}

This study was limited by the short amount of time that the author had to carry out the research in Ecuador and a small sample size of teachers. Due to time constraints, the author was only able to spend two weeks in Ecuador gathering data. In this time, he was able to visit eight schools, which limited the sample to eight teachers. Originally, he had intended to observe a classroom in each school in order to obtain more qualitative data about teacher pedagogies and the implementation of the curriculum in each classroom. This would have allowed the author to more fully develop an analysis of current teaching practices against the framework that was developed in the literature review. In future research, it will be important to include a greater representation of teachers in the sample and observe their teaching methods in order to gain a better understanding of how citizenship education curriculum is being implemented in Ecuador.

\section{Conclusion}

Education should go beyond the four walls of the classroom, Citizenship education should empower students to participate in their communities and become agents of change. Activities and projects provide students with an education that engages them and allows them to act upon their knowledge in order to become critical thinkers. Many of these activities are simple, but they provide valuable experiences through which students can develop their skills as creators of positive change. It is through such projects that education can be linked to action, as described in the framework.

Citizenship education is a vital component of education that, when administered correctly, empowers students to develop into citizens capable of improving the quality of life available to all people in their country and communities. Courses should be highly participatory, democratic, based on open and constructive dialogue, and 
linked to action through community and global projects. Classes that follow this framework will help students to learn the skills they need to become active agents of change.

The introduction of a citizenship education course in Ecuador in the last two years is a positive step in the right direction for the country's progress. The intended curriculum is meant to transform the students' educational experience so that they can begin to transform their communities. These courses are capable of integrating knowledge and action so that students can exercise their rights as citizens within the classroom setting as well as outside of it.

Based on survey answers, the majority of students feel that their citizenship education course is relevant, applicable, and interesting. Many students understand that one of the main objectives of the class is to help them become better citizens. However, the way that the curriculum is currently being presented, the majority of students are not given opportunities to act on the knowledge that they acquire in class. Classrooms are not as participatory or democratic as the framework prescribes, there is a lack of open dialogue between students and teachers, and the majority of students are not acting on their citizenship education through community and global projects. In order for the outcomes of citizenship education courses in Ecuador to align more closely with their intended effect, teachers need to employ more effective teaching methods and be equipped with the necessary resources required by the curriculum.

The author observed throughout the course of the study that there was a disparity between the resources available to schools in the urban and rural regions. In one of the nicer schools that was visited in Quito, the principal and vice-principal were out of the school for the day meeting with the President. High profile schools such as this one were equipped with everything they needed, such as smart boards, projectors, textbooks and DVD players. However, the schools that were visited in remote areas showed little evidence of investment from the government. In these schools, which were further from major cities and difficult to access, teachers and students lacked resources such as textbooks and DVD players. They also lacked a healthy environment for learning. In a few classrooms, despite the weather being 100 degrees outside, there were no fans to keep the teachers and students comfortable. Students in one classroom each brought their gym towels to class and used them as handheld fans just to get through the day. It is important that changes be made so that students in all schools in Ecuador have equal access to citizenship education courses that are supported by the necessary resources. This is essential to helping all students find their voice and grow in their potential as active citizens, so that one day they can help to improve other disparities that hinder the progress of the marginalized people of Ecuador.

\section{References}

Appreciation. (2014). In Merriam-Webster's online dictionary. Retrieved June 20, 2014, from http://www.merriam-webster.com

Arana, L. F. (2007). Campaign for education in democratic citizenship, Guadalajara, Mexico. Community Development Journal, 42(4), 482-489. https://doi.org/10.1093/cdj/bsm038

Banks, J. (2008). Diversity, Group Identity, and Citizenship Education in a Global Age. Educational Researcher, 37(3), 129-139. https://doi.org/10.3102/0013189X08317501

Cox, C., Jaramillo, R., \& Reimers, F. (2005). Education for Democratic Citizenship in the Americas: An Agenda for Action. Washington, DC: Inter-American Development Bank.

Dewey, J. (1916). Democracy and education. Carbondale: Southern Illinois University Press.

Harber, C., \& Mncube, V. (2012). Education, democracy and development: Does education contribute to democratisation in developing countries? Oxford, U.K.: Symposium Books, Ltd.

Hart, R. A. (1997). Children's participation. New York: UNICEF.

Heater, D. (1990). Citizenship: The Civic Ideal in World History, Politics and Education (p. 336). Longman, London.

Inter-American Institute for Human Rights (IIDH). (2007). Second Inter-American Report On Human Rights Education-A Study in 19 Countries. San Jose: IIDH.

Livo, N. J., \& Rietz, S. (1986). Storytelling: Process and Practice. Littleton, CO: Colorado Libraries Unlimited, Inc.

Ministry of Education (MOE). (2012a). Lineamientos curriculares para el bachillerato general unificado: EDUCACIÓN PARA LA CIUDADANÍA II. Quito: Ministry of Education.

Ministry of Education (MOE). (2012b). MARCO LEGAL EDUCATIVO: Constitución de la República, Ley 
Orgánica de Educación Intercultural y Reglamento General. Quito: Ministerio de Educación del Ecuador.

Parker, W. (1996). "Advanced" ideas about democracy: Toward a pluralist conception of citizen education. Teachers College Record, 98, 104-125.

Schulz, W., Ainley, J., Freidman, T., \& Leitz, P. (2009). Students' civic knowledge. In ICCS 2009 Latin America Report: Civic knowledge and attitudes among lower-secondary students in six Latin American countries (pp. 31-40). Amsterdam: International Association for the Evaluation of Educational Achievement.

Sen, A. (1999). Development as freedom. New York: Knopf.

Tibbitts, F. (2002). Understanding What We Do: Emerging Models for Human Rights Education. International Review of Education, 48(3/4), 159-171. https://doi.org/10.1023/A:1020338300881

Torney-Purta, J., \& Amadeo, J. A. (2004). Civic and Political Participation (pp. 75-90). Generalized Trust and Trust in Institutions (pp. 91-96). Strengthening Democracy in the Americas through Civic Education: An Empirical Analysis Highlighting the Views of Students and Teachers. Washington, DC: Organization of American States.

UNESCO. (2010a). Citizenship Education: Home Teaching and Learning for a Sustainable Future. UNESCO. Retrieved June 28, 2014, from http://www.unesco.org/education/tlsf/mods/theme_b/mod07.html?panel=1\# top

UNESCO. (2010b). Storytelling: Home Teaching and Learning for a Sustainable Future. UNESCO. Retrieved June 28, 2014, from http://www.unesco.org/education/tlsf/mods/ theme_d/mod21.html?panel=4\#top

World Bank. (2014). Expenditure on education as \% of total government expenditure (\%). Retrieved May 19, 2014, from http://data.worldbank.org/indicator/SE.XPD.TOTL.GB.ZS/countries/ECXJ?display=graph

\section{Copyrights}

Copyright for this article is retained by the author(s), with first publication rights granted to the journal.

This is an open-access article distributed under the terms and conditions of the Creative Commons Attribution license (http://creativecommons.org/licenses/by/4.0/). 